\title{
Revision of the Carboniferous genus Rhodeites Němejc from European and American localities
}

\author{
JOSEF PŠENIČKA \& STEPHAN SCHULTKA
}

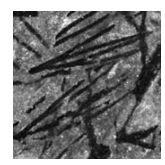

\begin{abstract}
The paper deals with two Pennsylvanian species Rhodeites gutbieri (Ettingshausen) Němejc and Rhodeopteridium subpetiolatum (Potonié) comb. nov. which are mostly mistakenly placed into one species Rhodea subpetiolata (Potonié) Zeiller. The clear differences between the two species are given. This paper focuses on their morphological details (including cuticle), as well as stratigraphical and geographical distributions. The genus Rhodeites is emended. Only sterile specimens of Rhodeites are known up till now and so the systematic position is still unknown. This paper also discusses their ecological status in nature. $\bullet$ Key words: Pennsylvanian, Rhodeites, Rhodeopteridium, cuticle.
\end{abstract}

PŠENIČKA, J. \& SCHULTKA, S. 2009. Revision of the Carboniferous genus Rhodeites Němejc from European and American localities. Bulletin of Geosciences 84(2), 241-256 (14 figures). Czech Geological Survey, Prague. ISSN 1214-1119. Manuscript received October 23, 2008; accepted in revised form April 9, 2009; published online May 24, 2009; issued June 30, 2009.

Josef P̌̌enička, Palaeontology Department, West Bohemian Museum in Pilsen, Kopeckého sady 2, 30100 Plzeñ, Czech Republic; jpsenicka@zcm.cz•Stephan Schultka, Museum für Naturkunde zu Berlin, Invalidenstrasse 43, 10115 Berlin, Germany; stephan.schultka@mfn-berlin.de

This paper deals with the poorly known Pennsylvanian species of the genera Rhodeites Němejc (1928) and partly Rhodeopteridium Zimmermann (1959), which are quite characteristic for Mississippian macrofloras. Many species from both genera have been placed in the genus Rhodea Presl in Sternberg. Both genera comprised many species which were primarily regarded as members of the rhacopterids, rhodeopterids or palmatopterids, which implies they were mainly pteridosperms. The paper is focused on two species, Rhodeites gutbieri (Ettingshausen) Němejc and Rhodeopteridium subpetiolatum (Potonié) comb. nov. which are usually mistakenly placed in one species Rhodea subpetiolatum (Potonié) Zeiller. Both species (Rhodeites gutbieri and Rhodeopteridium subpetiolatum) are only known from a few fragmentary specimens. Due to this fact, few palaeobotanists have taken an interest in these species, with the exception of Potonié (1889), Zeiller (1899), Gothan (1912, 1913, 1929), Kidston (1923), Němejc (1928, 1937) and Josten (1991). Known specimens of both species come from localities in Europe [from Germany (Potonié 1889, Gothan 1912), the UK (Kidston 1923), from the Czech Republic (Němejc 1928), Poland (Potonié 1889)], Turkey (Zeiller 1899) as well as West Virginia (USA) (e.g., Gillespie et al. 1978). Němejc (1928) described the largest specimen of Rhodeites gutbieri where the ultimate pinnae are attached to a penultimate rachis in pairs. It represents a quite different pattern of frond composition than that found among rhacopterids, rhodeopterids or palmatopterids. Němejc's specimen, which represents the best preserved specimen of Rhodeites, is housed in the National Museum in Prague under number E 4942. It comes from mines between Blatnice and Doubrava villages, Pilsen Basin (Czech Republic). Based on observations of this specimen, Němejc (1937) correctly established a new genus Rhodeites. We present for the first time morphological details of Rhodeites gutbieri together with its cuticles based on a redescription of Němejc's specimen, and other specimens from the Doubrava locality (Pilsen Basin) and Svinná locality (Radnice Basin; Gothan's descriptions of two specimens). We also emend the generic diagnosis of Němejc's Rhodeites. Rhodea subpetiolata s.s. is replaced by Rhodeopteridium subpetiolatum (Potonié) nov. comb. based on morphological characters. This paper establishes clear differences between the species Rhodeites gutbieri and Rhodeopteridium subpetiolatum (Potonié) nov. comb. which are frequently confused. Nevertheless, all known specimens of Rhodeites gutbieri and Rhodeopteridium subpetiolatum are, however, sterile so that is difficult to establish their systematic position. Němejc (1928) mentioned the possibility of a relationship between Rhodeites gutbieri and true ferns. Based on new observations we suggested a concept about the general plant form. 


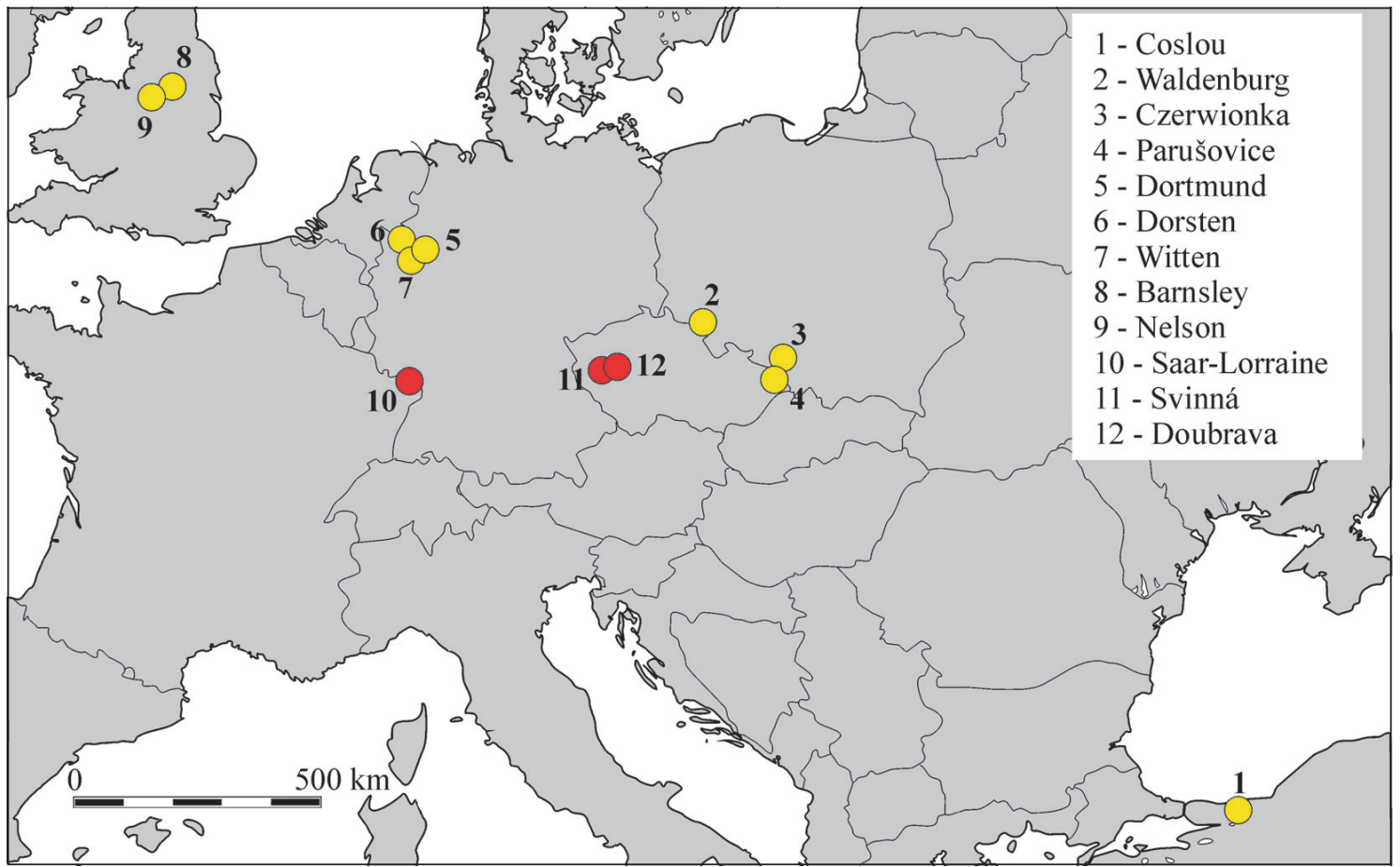

Figure 1. Map of occurrence of Rhodeites gutbieri (red dots) and Rhodeopteridium subpetiolatum (yellow dots).

\section{Historical background}

Ettingshausen [1854, p. 37, pl. 19, fig. 1 and 2 (see Fig. 2)] described and figured Sphenopteris gutbieri Ettingshausen. This species was established based on two specimens that came from the Svinná locality (Fig. 1) (Radnice Basin), from the Kladno Formation, Radnice Member (Bolsovian), Whetstone Horizon. This species was forgotten for a long time until Němejc (1937) took note of similarities between Ettingshausen's specimens and Potonié's Rhacopteris subpetiolata. He held that Sphenopteris gutbieri and Rhacopteris subpetiolata are the same species and synonymised them under the name Rhodeites gutbieri as Ettingshausen's name had nomenclatural priority (Ettingshausen, 1854 versus Poonié, 1889). It is not clear why later Němejc (1963) returned to the combination Rhodeites subpetiolata (including Ettingshausen's specimens) which is wrong according to the Botanical code (IBCN). Němejc (1937) also referred Rhodea lemayi Broussier \& Bertrand, 1911 to Rhodeites gutbieri, but we do not agree with this as each pinnule lamina of Rhodea lemayi has a blunt tip while the pinnule laminae of Rhodeites gutbieri have acute tips.

Potonié (1889, p. 27) established Rhacopteris subpetiolata Potonié based on poorly preserved compression material (see Fig. 10) from the Walbrzych locality (Fig. 1), Intrasudetic Basin (Waldenburg Formation; Serpukhovian-Bashkirian). The type material consists of one specimen representing a fragmentary penultimate rachis with two unattached ultimate pinnae. This specimen is now stored in the palaeobotanical collections of the Museum für Naturkunde zu Berlin with the inventory numbers MB.Pb. 2003/0960 together with five specimens later figured by Gothan (1912, 1913, 1929). Potonié (1889) referred his species to the rhacopterids based on the character of the venation and the type of pinnules. Later Zeiller (1899) described specimens of Rhodea subpetiolata from the Coslou locality (Fig. 1) near the Héraclée Basin (Turkey), Coslou Formation, Asturian. Zeiller (1899) referred his specimens to the genus Rhodea, and pointed out that this genus belongs to the Sphenopterids and that his Rhodea subpetiolata belongs to the "natural" relationship between Rhodea stachei Stur and Rhodea filifera Stur. Nevertheless, his specimens were fragmentary such that it is very difficult to prove genuine relationships. Gothan (1912) described other fragmentary material from the mine Germania, near Dortmund (Ruhr Basin) ("Fettkohle", stratigraphical position: Langsettian) (Fig. 1). One year later Gothan (1913) described additional fragmentary material from the Upper Silesian Basin [Séria Mulowcowa, Orzesche Member (i.e. the same as the "obere Muldengruppe"), Duckmantian; borehole near Rybnik (Czervionka and Parušovice, $460 \mathrm{~m}$ depth)]. Later Gothan (1929) described better preserved material from the Dorsten and Witten area (Stratigraphical Position Yeadonian/Langsettian) (Fig. 1). Kidston (1923) figured specimens of Rhodea subpetiolata and Rhodea gutbieri from the "Westphalian Series" of Great Britain, of Duckmantian age. Stopa (1957) figured a specimen with Zeilleria-like fertile 

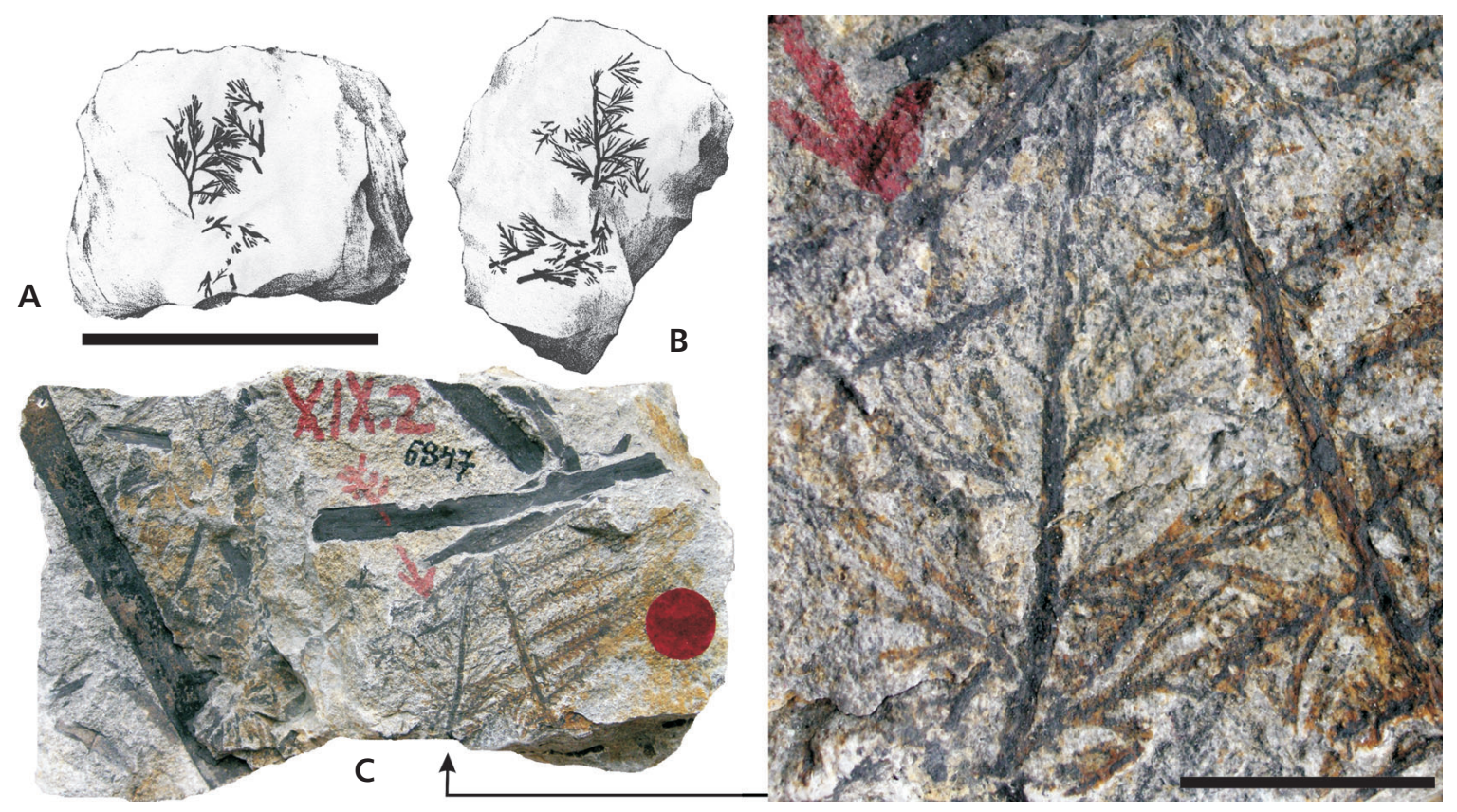

Figure 2. Ettingshausen's specimen of Sphenopteris gutbieri Ettingshausen from the Svinná locality, Radnice Basin, Czech Republic. • A - Ettingshausen (1854), pl. 19, fig. 1. B - Ettingshausen (1854), pl. 19, fig. 2. • C - lectotype of Rhodeites gutbieri (Ettingshausen) Němejc, GBA 1854/009/0021 [pl. 19, fig. 2 in Ettingshausen (1854)]. A, B, C - scale bar $50 \mathrm{~mm} ; \bullet$ D - detail of figure 2C. Part of ultimate pinna with pinnules: scale bar $10 \mathrm{~mm}$.

organs which should belong to Rhodeopteridium subpetiolatum. Brousmiche (1983) and Daber (2003) described specimens of Sphenopteris coemansii Andrae from the Sarro-Lorrain Basin (Bolsovian) which are markedly similar to Rhodeites gutbieri. Nevertheless, material studied by these authors are strictly sterile and only the pinnule's shape can be observed, nothing is known about the general character of the whole plant or about the reproductive organs.

Rhodea was established by Presl in Sternberg (1838) as a quite artificial genus. Because Rhodea Presl is a junior homonym of Rhodea Endlicher, which is an invalid synonym of the monocotyledon Rhodea Roth (Jennings 1976), Zimmermann (1959, p. 280) proposed the new generic name Rhodeopteridium for this group of fronds.

\section{Material and method}

Material. - Material published in this paper came from the depositories of the West Bohemian Museum in Pilsen (F 44), National Museum in Prague (E 4942), Museum für Naturkunde in Berlin (MB.Pb.2003/0209, 2003/0212, 2003/213, 2003/0214 und 2003/0788), Geologische Bundesanstalt in Vienna (GBA 1854/009/0021) and British Geological Survey, Keyworth (UK; Kidston collection; specimen Nos. 4091, 3441 and 3440).

Specimens from the West Bohemian Museum and National Museum in Prague come from old and now inactive mines between Doubrava and Blatnice, near Nýřany (Pilsen Basin; Czech Republic) (Fig. 1). Specimens housed in the Geologische Bundesanstalt in Vienna derive from the Svinná locality (Fig. 1) (Radnice Basin; Czech Republic). These specimens were collected from the Whetstone Horizon of the Radnice Member (Kladno Formation; Bolsovian) and they are preserved as "three-dimensional compressions" in yellow tuff.

Specimens housed in the Museum für Naturkunde zu Berlin are preserved in gray coloured claystone to coarse siltstones. The holotype of "Rhacopteris" subpetiolata, MB.Pb. 2003/960, sampled in 1887 and published by Potonié (1899), originated from the "Fürstlicher Tiefbau" near Waldenburg (Wałbrzych). Specimen MB.Pb.2003/214 (Gothan 1912, pl. 3, fig. 6) came from the mine Germania, near Dortmund (Fig. 1) (Langsettian); specimen MB.Pb.2003/209 (Gothan 1929, pl. 1, fig. 2) came from the mine Helene-Tiefbau, near Witten (Fig. 1) (Yeadonian/ Langsettian) and specimen MB.Pb.2003/212 (Gothan 1929, pl. 6, fig. 4) came from the coal 4, mine Baldur, near Dorsten (Fig. 1) (Duckmantian). Additional specimens came from the "Steinernes Kreuz" near Wałbrzych, mine Victor, near Neu-Lässig and mine Gustav between Rothenbach and Schwarzwaldau.

Specimens housed in the British Geological Survey, Keyworth (UK) came from the Pennine Coalfield. Specimens are preserved in grey coloured claystone. They are from Kidston's collection and were published by Kidston (1923, pl. 59). Specimen No. 4091 came from the Ward Green locality (Fig. 1) near Barnsley (Yorkshire) and belongs to Barnsley Coal (Westphalian Series; Duckmantian). Specimens No. 3441 and 3440 came from the 


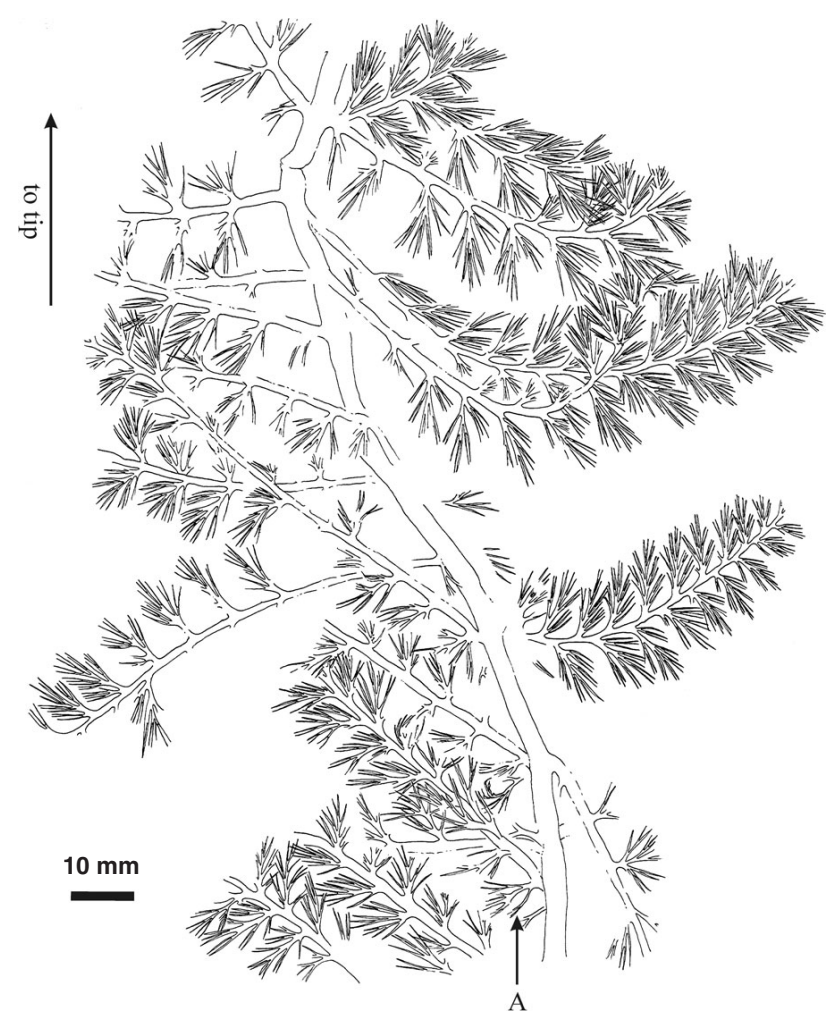

Figure 3. Rhodeites gutbieri Ettingshausen (Němejc); specimen E 4942; camera lucida drawing; (A) indicates aphlebia-like organs.

Hibson Road locality (Fig. 1) at Marsden Height (Arley Mine), Nelson (Lancashire) and belong to the Westphalian Series, Duckmantian.

Maceration. - Cuticles were isolated from specimens with the aid of 35 percent hydrofluoric acid for 22 hours. Subsequently, cuticles were washed in distilled water, dried and examined under a CAMECA SX100 scanning electronic microscopes (SEM). All SEM samples were gold-coated. Cuticles were quite destroyed during maceration in Schulze's solution due to the high degree of oxidation of the cuticles. All digital photos of cuticles are stored in the West Bohemian Museum, Pilsen.

\section{Description of Rhodeites gutbieri}

Description of lectotype of R. gutbieri. - Specimen (GBA 1854/009/0021) shows part of an ultimate pinna (Fig. 2C, D).
The ultimate rachis is $1 \mathrm{~mm}$ wide. Pinnules are of a palmatopterid-type and alternate on the ultimate rachis at an angle of $30^{\circ}-40^{\circ}$ (Fig. 2D). The distance between two pinnules is about $5 \mathrm{~mm}$. The pinnules are $10 \mathrm{~mm}$ long and $7 \mathrm{~mm}$ wide. Pinnules are up to 7 times segmented. Each segment is differentiated in up to 4 laminar lobes with sharp tips. The midvein is well marked when leaving the ultimate rachis. Lateral veins are dichotomously divided up to 3 times and veins run into laminar lobe (Fig. 2D).

Description of other specimens of R. gutbieri from the Pilsen Basin. - Specimens [E 4942 (Figs 3, 4A) and F 44 (Fig. 5A)] show part of a penultimate pinna. The penultimate rachis is more than $160 \mathrm{~mm}$ long and $3 \mathrm{~mm}$ wide, sinusoidely warped. This rachis is partly anatomical preserved and possibly there are tracheids (Fig. 4C). These tracheids are 35-40 $\mu \mathrm{m}$ wide; nevertheless, it is not possible to establish their length and details due to their poor preservation. The rachis is densely covered by uniseriate, multicellular trichomes $0.2-0.4 \mathrm{~mm}$ long (Fig. 4E, arrowed). Ultimate pinnae are more than $120 \mathrm{~mm}$ long and 22-30 mm wide (Figs 3, 4A). The length and width of ultimate pinnae depends on the position in the whole frond. They are gradually tapering from about their middle part to the tip (Figs 3, 4A, B). The tips of ultimate rachies show poor differentiated lobes with very narrow lamina. Ultimate rachies are straight or very slightly sinusoidal at the distal end of the ultimate pinna and are 1-1.2 mm wide (Fig. 4B). Nevertheless, the divergence is still unknown. Ultimate rachises are attached to their penultimate rachis in pairs (Fig. 3) as specimens E 4942 shows. It is impossible to decide if two opposite ultimate pinna leave the rachis together (V-shaped as is known in Zygopterid ferns) or if two ultimate pinnae show an opposite position.

Pinnules are palmatopterid-type, which is characteristic for Palmatopteris-type and Rhodea-type plants, alternating on ultimate rachis at angles of $30^{\circ}-40^{\circ}$ (Fig. 4D). They are $10-13 \mathrm{~mm}$ long and $6-8 \mathrm{~mm}$ wide. Pinnules are up to 7 times segmented. Each segment is differentiated into up to 4 laminar lobes with sharp tips (Fig. 4D) which corresponds with the lectotype. The midvein is preserved as marked central lamina (Fig. 5B arrow). Lateral veins branch off with angles of around $40^{\circ}$ to $70^{\circ}$, running in every laminar segment of the pinnules (Fig. 5B). Lateral veins are divided up to 3 times (Fig. 4D). Interesting are pinnules located near the base of the ultimate pinna (on the lower side) which probably represent aphlebia-like organs

Figure 4. Rhodeites gutbieri (Ettingshausen) Němejc; specimen E 4942 from the the Doubrava locality, Pilsen Basin; the best and most well known specimen. $\bullet \mathrm{A}$ - part of penultimate pinna with several incomplete ultimate pinnae. Arrow shows aphlebia-like organs: scale bar $10 \mathrm{~mm}$. $\bullet \mathrm{B}-\mathrm{detail}$ of distal part of ultimate pinna with palmatopterid-type pinnules: scale bar $10 \mathrm{~mm}$. $\mathrm{C}$ - detail of penultimate rachis with clearly visible tracheids: scale bar $1 \mathrm{~mm}$. $\bullet \mathrm{D}$ - detail of palmatopterid-type pinnule with midvein (arrowed) in central part of pinnule and lateral veins once or three time divided: scale bar $10 \mathrm{~mm}$. $\bullet \mathrm{E}$ - margin of ultimate rachis with several uniseriatre, multicellular trichomes (arrows): scale bar $200 \mu \mathrm{m}$. 


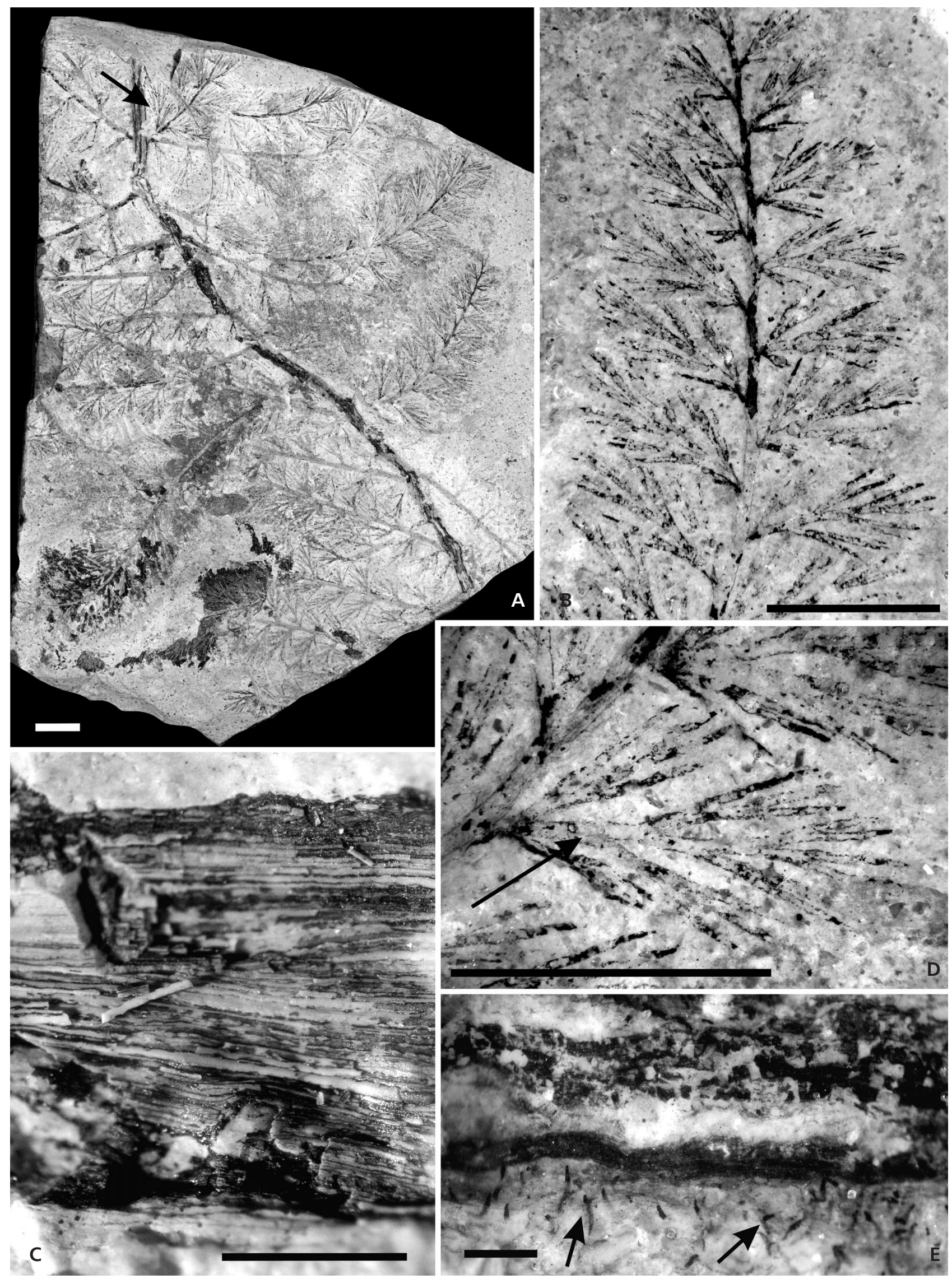




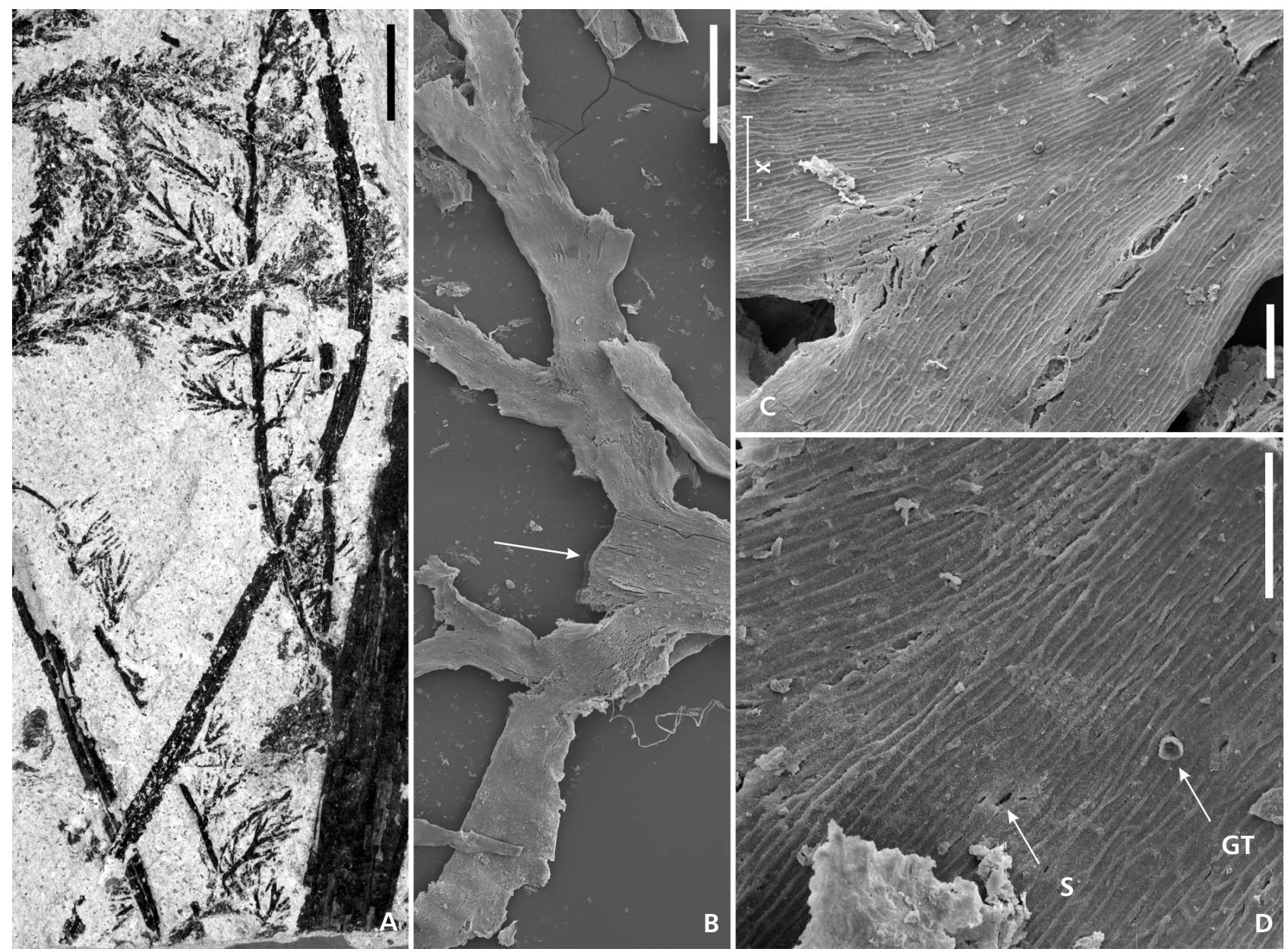

Figure 5. Rhodeites gutbieri (Ettingshausen) Němejc; specimen F 44 from the Doubrava locality, Pilsen Basin, Czech Republic. • A - fragment of penultimate rachis with incomplete ultimate pinnae. Pinnules are fragmentarily preserved. Rhodeites gutbieri is associated with Selaginella-like shoots: scale bar $10 \mathrm{~mm}$. B - middle part of palmatopterid-type pinnules. Central part of pinnule is represented by midvein (arrow). This part is covered by glandular trichomes. Lateral veins arise from the midvein: SEM, scale bar $1 \mathrm{~mm}$. $\bullet \mathrm{C}$ - adaxial cuticle with well preserved cells. Cells of costal field (X) correspond with vein. This field is characterised by elongate and narrow cells: SEM, scale bar $100 \mu \mathrm{m}$. $\bullet$ D - detail of abaxial cuticle with stomata (S) and basal part of glandular trichomes (GT): SEM, scale bar $100 \mu \mathrm{m}$.

(Fig. 3 "A" and Fig. 4A, arrowed). These pinnules are wider than other pinnules and they have a more complicated construction (richer differentiation of lamina-type lobes).

Cuticles: Cuticle of abaxial as well as adaxial side is thick and more or less identical, but there is a difference in the number of stomata per $\mathrm{mm}^{2}$. Stomata are very rare on both abaxial and adaxial sides. The adaxial cuticle has 4 stomatal apparatuses per $1 \mathrm{~mm}^{2}$ (stomatal index 0.3 ) while the abaxial cuticle has 8 stomatal apparatuses per $1 \mathrm{~mm}^{2}$ (stomatal index 0.6).

Cells of adaxial (Fig. 5C, D and Fig. 6A, B) and abaxial (Fig. 7 and Fig. 6C, D) cuticles are differentiated in costal and intercostal fields but the margins of both fields are obscure. Therefore, the cells in the area of the veins ("costal field") appear somewhat narrower and longer (Figs 5C "X", 6A, B, D all "X", 7C "X"). Costal cells are 80-170 $\mu \mathrm{m}$ long and 5-12 $\mu \mathrm{m}$ wide, elongate and tetragonal (polygonal). The cells of intercostal field are 20-140 $\mu \mathrm{m}$ long and $10-50 \mu \mathrm{m}$ wide, elongate and tetragonal (polygonal) (Fig. 7C arrow). Anticlinal walls of cells of both fields are straight.

Adaxial and abaxial cuticles are covered by glandular trichomes placed mainly on costal fields (Figs 5D "GT", 6D "GT"). Glandular trichomes are not well preserved themselves but they are represented by trichome bases, 10-15 $\mu \mathrm{m}$ in diameter (Figs 6B, C, D all "G", 7B “G”, D). It is rarely possible to see whole or partly destroyed glandular trichomes (Fig. 7B, E-H). Trichome bases are 40-50 $\mu \mathrm{m}$ in diameter and trichomes are 50-60 $\mu \mathrm{m}$ long. Trichomes consist of a basal cell (Figs 7E, F, 8 "BC") and globose bodies (Figs 7H, 8 "BO”). Uniseriate multicellular trichomes which occur on rachises do not occur on pinnules. 

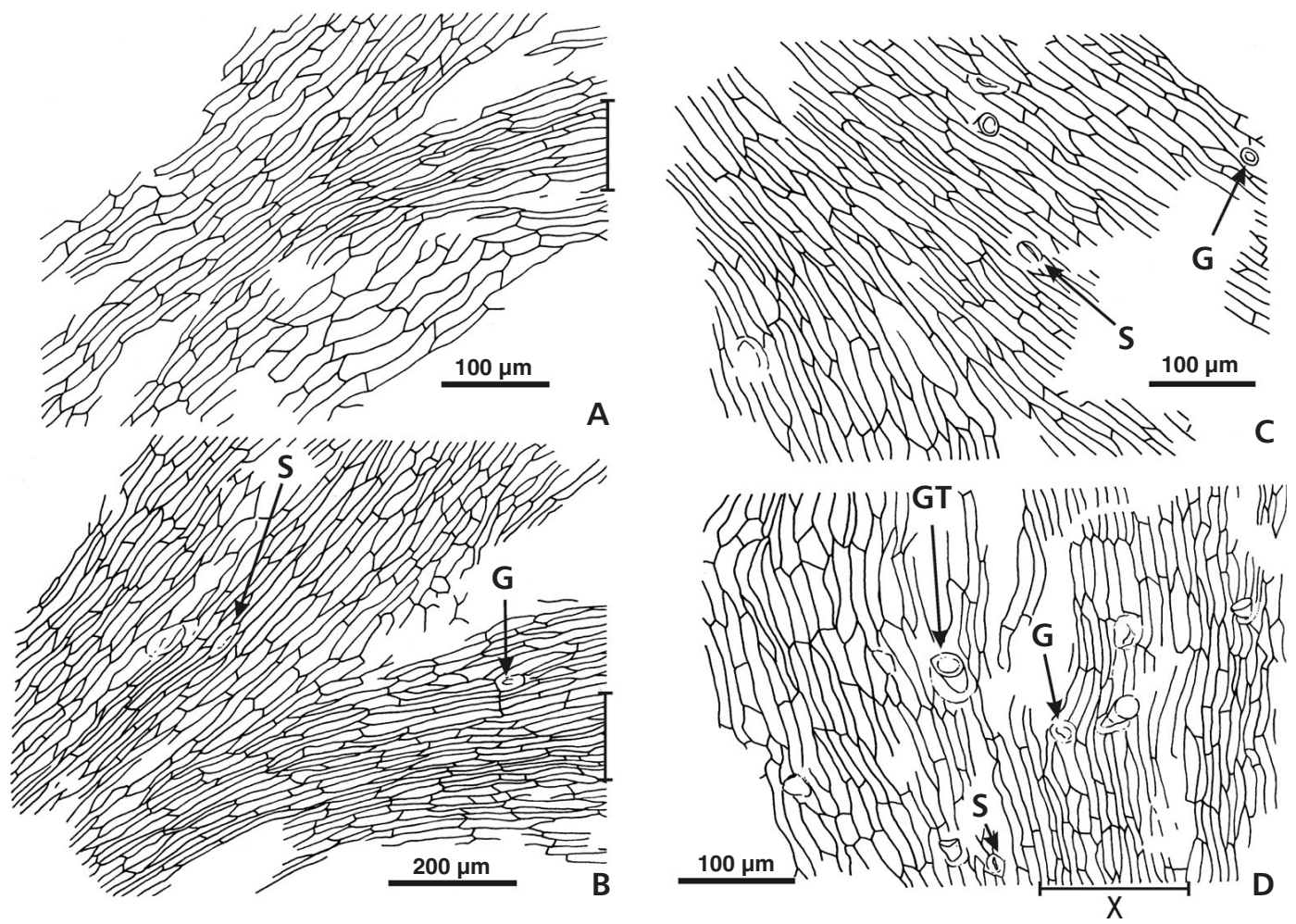

Figure 6. Cuticles from Rhodeites gutbieri (Ettingshausen) Němejc; specimen F 44. • A - adaxial cuticle with cells of costal field (X) and intercostal field: based on unpublished SEM photograph. $\bullet$ B - adaxial cuticle with cells of costal field (X) and intercostal field. Cuticle contains trichome bases (G) and stomata (S): based on Fig. 5C. $\bullet$ C - abaxial cuticle contains trichome bases $(\mathrm{G})$ and stomata (S): based on unpublished SEM photograph. $\bullet$ D - adaxial cuticle with cells of costal field (X). Abaxial cuticle contains trichome bases (G), glandular trichome (GT) and stomata (S): based on unpublished SEM photograph.

Stomata (Figs 5D "S", 6B-D all "S", 7C "S", 7A, 9) are irregularly restricted on cuticles (abaxial as well as adaxial), sunken (Fig. 7A), anomocytic type 20-27 $\mu \mathrm{m}$ long and 10-12 $\mu \mathrm{m}$ wide. Guard cells are 20-26 $\mu \mathrm{m}$ long and 4-5 $\mu \mathrm{m}$ wide (Fig. 7A). Subsidiary cells are not differentiated from ordinary cells.

\section{Description of Rhodeopteridium subpetiolatum}

Description of holotype of Rh. subpetiolatum. - The holotype (Fig. 10) shows a poorly preserved, $65 \mathrm{~mm}$ long, part of a penultimate pinna. The penultimate rachis is $6.5 \mathrm{~mm}$ wide, straight and finely striated. Attached are three proximal parts of ultimate rachises at an angle of nearly $60^{\circ}$ at distances of 17 and $13 \mathrm{~mm}$. They show an alternate threedimensional position.

Three ultimate pinnae are near the penultimate rachis, but are not attached and are broken at both ends. The fragments measure around $45 \mathrm{~mm}$ in length and are around $18 \mathrm{~mm}$ wide. The ultimate warty rachises look rigid, straight and are remarkably parallely embedded. Their width is 1.0 to $1.2 \mathrm{~mm}$.

The pinnules are of palmatopterid type, alternating with angles between $35^{\circ}$ and $50^{\circ}$. They are 10 to $13 \mathrm{~mm}$ long and around $5 \mathrm{~mm}$ wide. The pinnules are differentiated in up to four segments with one to three lobes. Lobes, if bifurcated, are up to $6 \mathrm{~mm}$ long, if unforked may be longer than $10 \mathrm{~mm}$, with 0.3 to $0.35 \mathrm{~mm}$ very narrow, lamina, proximally $0.2 \mathrm{~mm}$ wide, tapering and fusing with the veins at the end. The midvein is around $0.1 \mathrm{~mm}$ wide, running up to the tips. Tips are not preserved.

Description of Rh. subpetiolatum (Potonié) comb. nov. housed in Museum für Naturkunde zu Berlin. - The specimens MB.Pb.2003/209 (Fig. 11C), MB.Pb.2003/213 (Fig. 11B) and MB.Pb.2003/0214 (Fig. 11A) show distal ends of ultimate pinnae. Ultimate rachises are 0.6 to $0.8 \mathrm{~mm}$ wide, nearly straight with a somewhat rigid appearance. Pinnules alternate on the ultimate rachis (Fig. 11A, C) at acute angles around $30^{\circ}-50^{\circ}$. The gap on the ultimate rachis between two adjacent pinnules is 1.4 to $2.0 \mathrm{~mm}$. In specimen MB.Pb.2003/0209 the distance between each pinnule is 4.0 to $4.4 \mathrm{~mm}$. Pinnules are of palmatopterid-type, $10-15 \mathrm{~mm}$ long and 6-8 $\mathrm{mm}$ wide and are differentiated into lobed segments. There are up to four segments, each showing one to (seldom) four lobes. This ramification pattern corresponds with the vein's system. The lobes show very narrow laminae; their tips taper off. 

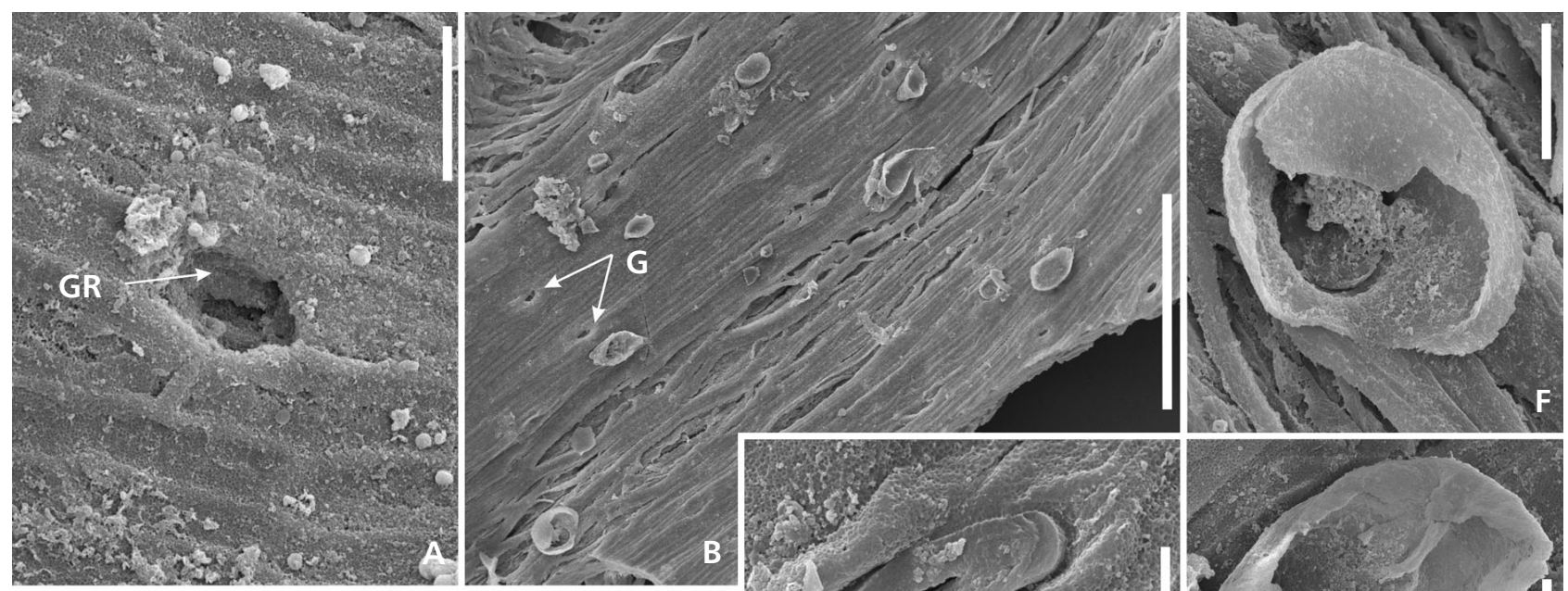

B
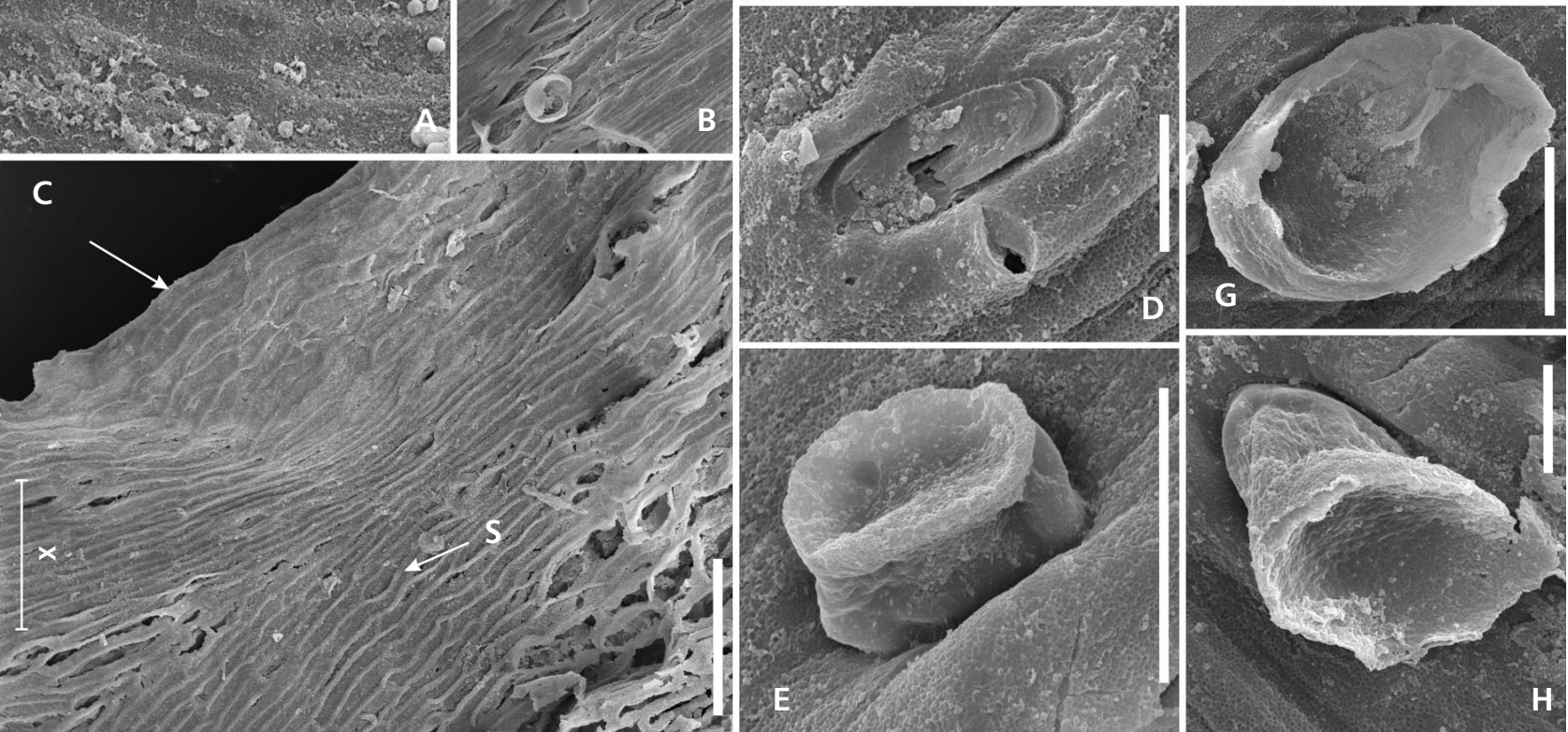

Figure 7. Rhodeites gutbieri (Ettingshausen) Němejc; specimen F 44 from Doubrava locality. $\bullet A$ - detail of sunken anomocytic stoma. Subsidiary cells are not separated from ordinary cells. Guard (GR) cells are well visible: SEM, scale bar $20 \mu \mathrm{m}$. B - abaxial cuticle densely covered by glandular trichomes or trichome bases (G). These trichomes are partly destroyed: SEM, scale bar $200 \mu \mathrm{m}$. $\bullet$ C-adaxial cuticle shows cells of intercostal (arrowed) and costal (X) fields: (S) represents stomatal apparatus: SEM, scale bar $200 \mu \mathrm{m}$. $\bullet \mathrm{D}$ - detail of trichome base of glandular trichome: SEM, scale bar $10 \mu \mathrm{m}$. - E - basal part of glandular trichome: SEM, scale bar $20 \mu \mathrm{m}$. $\bullet$ F - basal part of glandular trichome: SEM, scale bar $10 \mu \mathrm{m}$. $\bullet \mathrm{G}$ - open body of glandular trichome: SEM, scale bar $20 \mu \mathrm{m}$. $\bullet \mathrm{H}$ - open body of glandular trichome with visible basal part: SEM, scale bar $20 \mu \mathrm{m}$.

Specimen MB.Pb.2003/0788 (Fig. 11D) shows a straight penultimate rachis, $11.5 \mathrm{~mm}$ wide. Attached (Fig. 11D, arrowed) is a bent ultimate rachis, more than $66 \mathrm{~mm}$ long. This rachis is about $2 \mathrm{~mm}$ wide. Traces of attachments in slightly three-dimensional positions of two rachises are present at distances of 10 to $14 \mathrm{~mm}$, while the next two are attached at a distance of around $30 \mathrm{~mm}$. Pinnules are $12 \mathrm{~mm}$ long and around $6 \mathrm{~mm}$ wide, and of an outline described above; all lobes are broken.

The specimen MB.Pb.2003/0212 (Fig. 11E) from the Westphalian B of the Ruhr basin (Gothan 1919) shows a rhachis $74 \mathrm{~mm}$ long and $6 \mathrm{~mm}$ wide with attached pinnules around $11 \mathrm{~mm}$ long and $9 \mathrm{~mm}$ wide. They are attached at a distance varying from 3.5 to $11 \mathrm{~mm}$ (mostly around $8 \mathrm{~mm}$ ) and show a three-dimensional arrangement. One of the pinnules at the basis of a pinna does not look as compact as those described above and even does not show that rigidity. There is a pronounced main rachis (Fig. 11E "P") with up to five lateral segments branching off which show up to 5 lobes. This type of pinnule probably represents aphlebia-like organs (Fig. 11E, arrowed).

\section{Discussion}

The studied species have not been widely mentioned in the palaeobotanical literature, due to the rareness of well preserved specimens. There are only a few specimens where it is possible to describe more than the shape of the pinnules. Due to this fact we have poor information about the whole plant concept and furthermore, there is no knowledge about reproductive organs. Nevertheless, we are presenting here new information which allowed us to push forward knowledge of both studied species. 

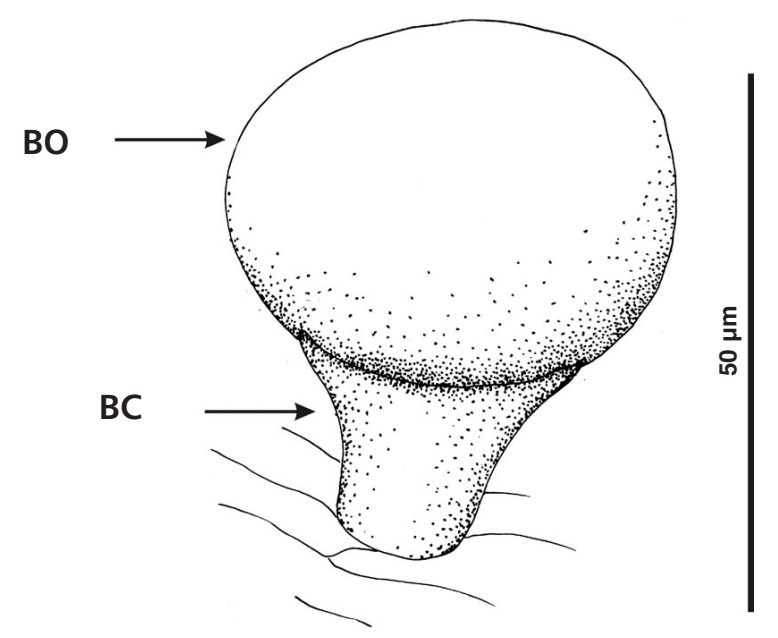

Figure 8. Reconstruction of glandular trichome, consisting of basal cell $(\mathrm{BC})$ and main body $(\mathrm{BO})$.

\section{Comparison of Rhodeites gutbieri and Rhodeopteridium subpetiolatum}

Rhodeites gutbieri and Rhodeopteridium subpetiolatum show a great degree of similarity but also clear differences. The main differences are the attachment of ultimate rachises to the penultimate axes, which is in pairs in $R$. gutbieri as already mentioned by Němejc (1928) while the material of Rh. subpetiolatum published by Gothan $(1913,1929)$ show a weak pseudohelical arrangement.

The pinnules of both species are of palmatopterid-type with deeply divided laminar lobes. But Rh. subpetiolatum described by Potonié (1889) and Gothan (1912, 1913, 1929) shows an alternating, three-dimensional position of the pinnae in comparison to $R$. gutbieri which shows clearly planated fronds. Another difference seems to be the width of the penultimate rachis. Potonié's and Gothan's specimens (Rh. subpetiolatum) show 6 to $11.5 \mathrm{~mm}$ wide penultimate rachises while $R$. gutbieri has a penultimate rachis of $3 \mathrm{~mm}$ width. Nevertheless, the width of the penultimate rachis depends on the position of the penultimate pinna in the frond, in that rachises situated near the base of a plant are wider than rachises at the distal end of the whole plant.

Generally, pinnules of $R$. gutbieri seem to be shorter than $R h$. subpetiolatum pinnules, which was also mentioned by Kidston (1923), but this character may be connected with too many environmental parameters to be of systematic relevance. In addition $R$. gutbieri may also show shorter pinnule stalks in comparison with $R h$. subpetiolatum (Fig. 12).

Kidston (1923) indicated shorter segments in R. gutbieri than in Rh. subpetiolatum, which also applies to the Czech and the German material respectively. Jennings (1976) believed in the taxonomic relevance of this character but it seems to be a weak one, like the occurrence of hairs (there are none in Rh. subpetiolatum).

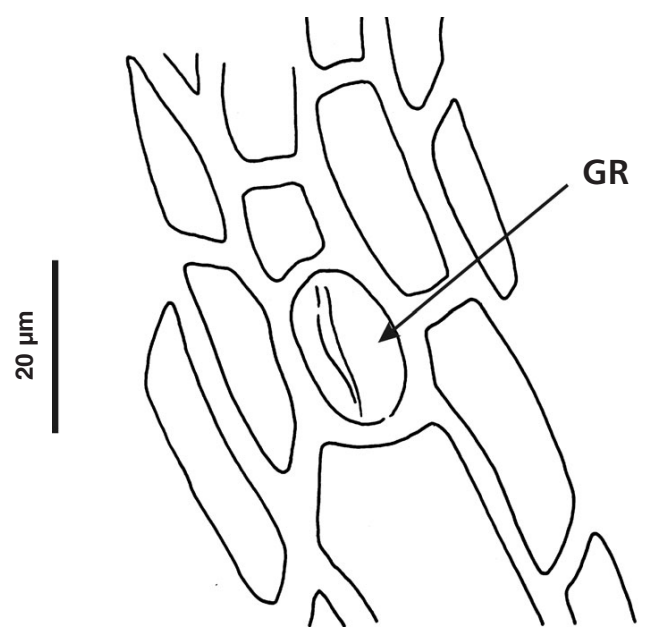

Figure 9. Anomocytic stoma surrounded by cells which are not differentiated from ordinary cells. (GR) - guard cells; based on unpublished SEM photograph.

There is also a difference in the latitude of the laminar lobes. The lobes of Rh. subpetiolatum (sensu Potonié/Gothan) are significantly narrower than $R$. gutbieri lobes, which are closer to the shape of pinnules of Sphenopteris (Rhodea) trichomanioides, the type-species of this group of foliage. Lastly $R$. gutbieri has laminar lobes divided three times (Fig. 12C) while Rh. subpetiolatum has laminar lobes divided no more than two times (Fig. 12D).

The somewhat different branching pattern together with the tendency of the lobes to bunch together and the resulting width of segments produces a more fan-like shape of pinnules in Rh. subpetiolatum (Remy \& Remy 1977 named it "birch-broom habit") which may be typical and a distinctive feature with regard to $R$. gutbieri.

\section{Comparison of studied species with other plants of similar pinnule-type}

Potonié $(1889,1899)$ placed this species (Rh. subpetiolatum) in Rhacopteris Schimper based on the similarity of pinnules which are differentiated into deep and sharp lobes that correspond with veins. Rhacopteris Schimper, 1869, is characterised as a plant with linear, pinnate frond, narrowing towards the base and contracted into a point at the apex; rachis straight or rarely slightly sinusoid, alternately organized rachises; pinnules flabelliform, semiflabelliform or rhomboidal, entire, crenate, lobed or divided into narrow linear segments, placed at right angles or slightly oblique to the axes (Schimper 1869, Kidston 1923). Pinnules of some Rhacopterids may appear like $R h$. subpetiolatum. Nevertheless, all known species of Rhodeopteridium, including the studied specimens, do not conform to the Rhacopteris characteristics, which corresponds with Zeiller's (1899), 

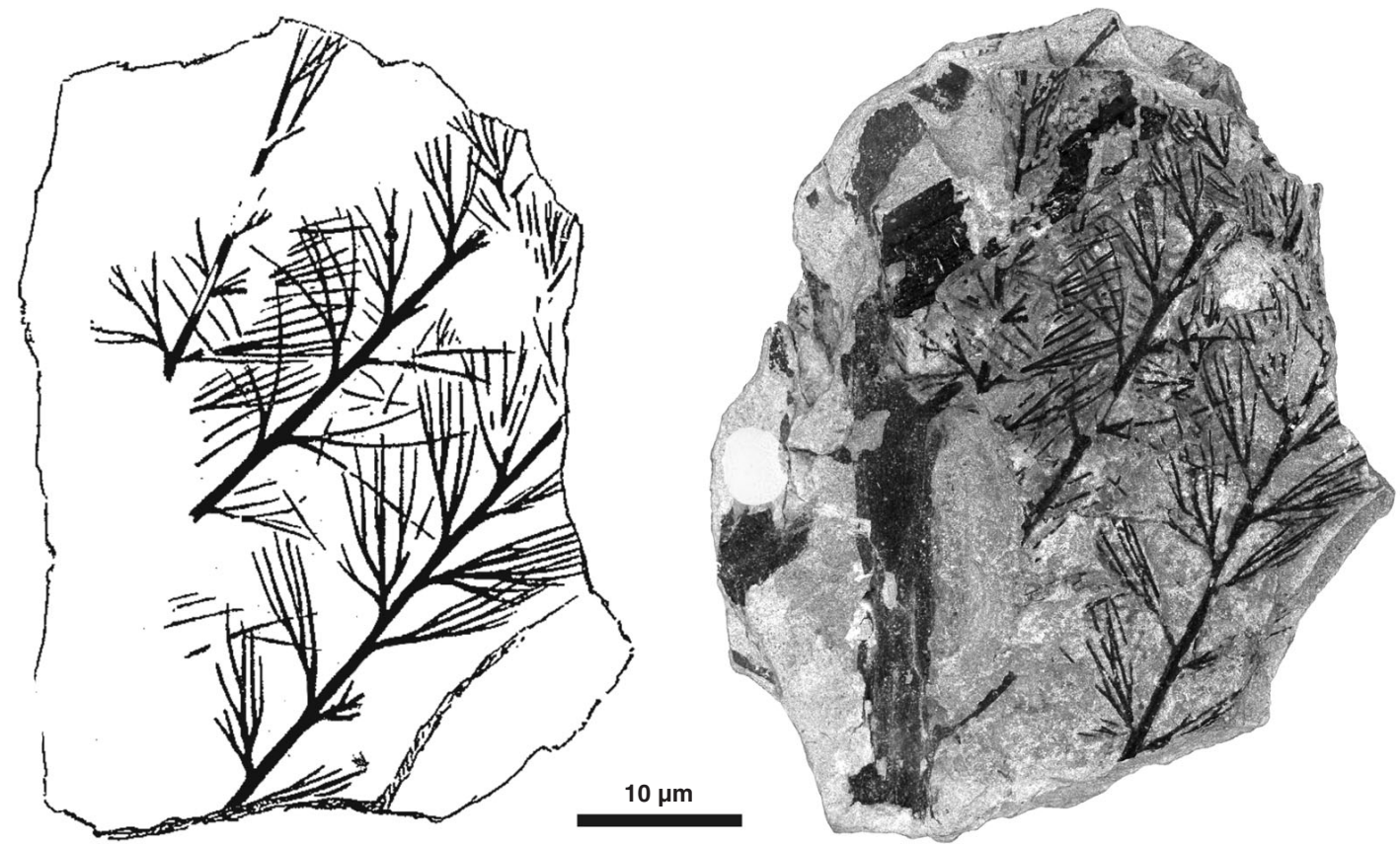

Figure 10. Rhodeopteridium (Sphenopteris) subpetiolatum (Potonié) comb. nov. $\bullet$ A - figured by Potonié (1889, p. 27) based on poorly preserved compression material from Intra-Sudetic Basin (Waldenburg Formation). B - holotype; MB.Pb. 2003/960; specimen corresponds with Potonié's (1889) figure (see Fig. 10A).

Gothan's (1912, 1913, 1929), Kidston's (1923) and Němejc's (1928) opinions. Consistently all the four authors assigned the studied species to the genus Rhodea Presl in Sternberg.

Rhodea was established by Presl in Sternberg (1838) as a quite artificial genus. Because Rhodea Presl is a junior homonym of Rhodea Endlicher, which is an invalid synonym of the monocotyledon Rhodea Roth (Jennings 1976), Zimmermann (1959, p. 280) proposed the new generic name Rhodeopteridium for this group of plants. Rhodeopteridium is characterised by pinnatifid fronds with sphenopterid pinnules, differentiated into very narrow laminar lobes. When such species are found in a fertile condition they are removed from Rhodeopteridium and placed in genera founded on characters derived from their fertile organs (for example Zeilleria Kidston et al.). Stur (1877) separated his new genus Diplotmema from Rhodea (Rhodeopteridium) based on the character of producing fronds with just one major dichotomy in its proximal part. Later Potonié (1892) separated from Stur's (1877) specimens (respectively species) the new genus Palmatopteris Potonié for fern-like plants with double dichotomy of the main rachis with sphenopterid pinnules, differentiated into very narrow laminar lobes.

Nevertheless, all three genera Rhodeopteridium, Diplotmema and Palmatopteris have rachises of all orders in alternate organization as in Rh. subpetiolatum and they are never organised in pairs as in $R$. gutbieri (specimen E 4942). Due to this fact Němejc (1928) suggested this spe- cies with palmatopterid-type pinnules, combined with paired ultimate pinnae, has to be placed into a different genus, for which a new genus was later established Rhodeites (Němejc 1937, p. 6). He characterised the new genus: "...the secondary pinnae are arranged in pairs on the stronger and more or less winded primary rachis; but no aphlebiae at the base of such pairs could be stated...".

Kidston (1923) had already proposed the idea that Rhodeites (Sphenopteris) gutbieri and Rh. subpetiolatum may be the same species. Only 15 years later, Němejc (1937) synonymized $R$. gutbieri and Rh. subpetiolatum, integrating both taxa within the species $R$. gutbieri which was later accepted by Josten (1991).

The robust character "arrangement of ultimate pinnae in pairs" supports our opinion confirming Rhodeites as a monospecific genus, clearly separated from the genus Rhodeopteridium, including all species showing pinnatifid fronds with sphenopterid or palmatopterid pinnules, differentiated into very narrow laminar lobes and with a three-dimensional, pseudohelical arrangement of ultimate rachises.

\section{Short comment on the affinity of Rhodeites gutbieri}

We stated above that only sterile specimens of Rhodeites are known up till now. Nevertheless, during maceration of Selaginella-like cones (specimen F 44; West Bohemian 

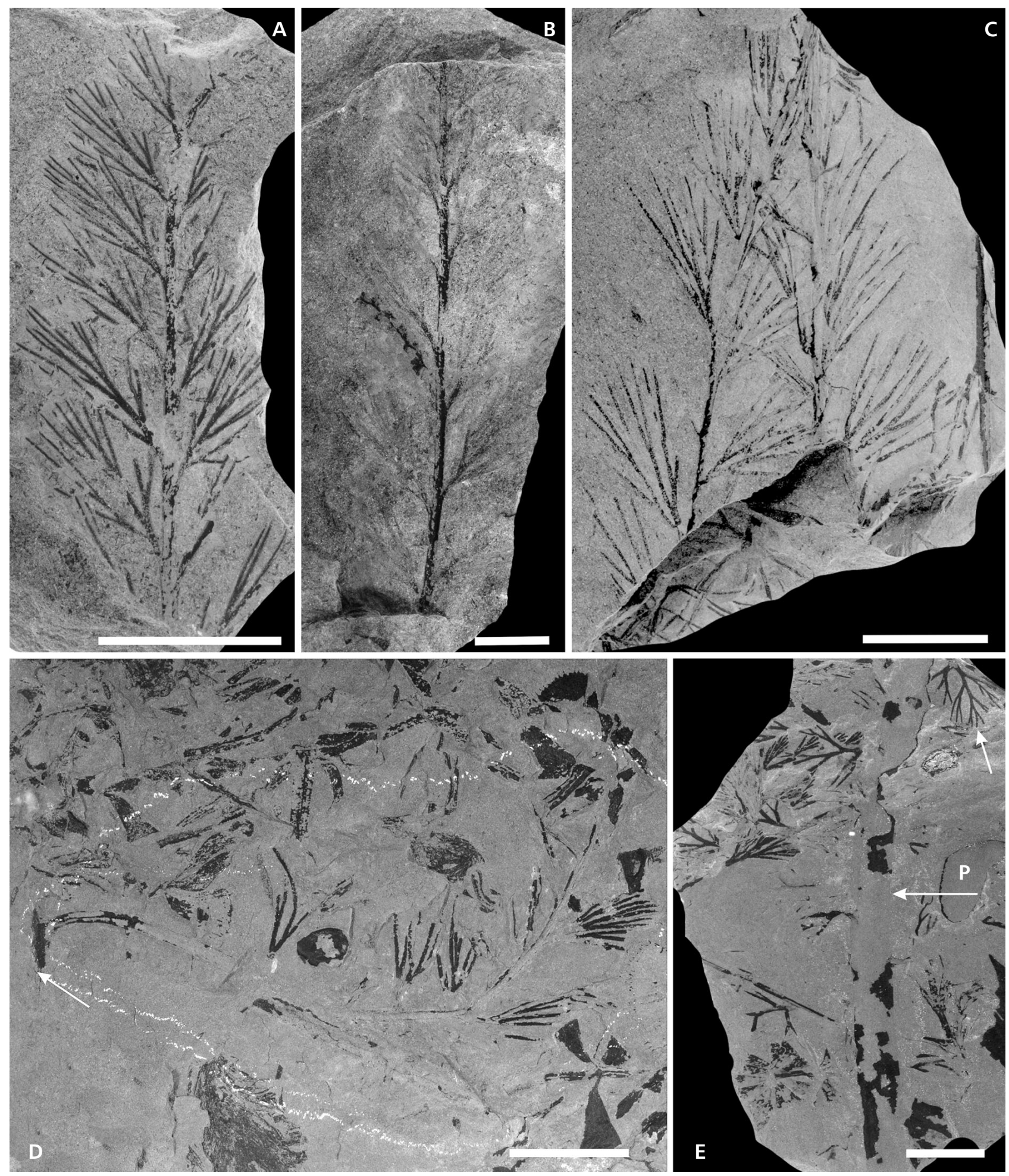

Figure 11. Rhodeopteridium subpetiolatum (Potonié) comb. nov. - A - part of distal end of ultimate pinna with well preserved pinnules: MB.Pb.2003/214 - Gothan (1912), pl. 3, fig. 6 (locality - mine Germania, Dortmund, Germany): scale bar $10 \mathrm{~mm}$. B - part of distal end of ultimate pinna with pinnules: MB.Pb.2003/213 - Gothan (1929), pl. 1, fig. 3 (locality - mine Germania, Dortmund): scale bar $10 \mathrm{~mm}$. C - distal part of two ultimate pinnae with palmatopterid-type pinnules: MB.Pb.2003/209 - Gothan (1929), pl. 1, fig. 2 (locality - mine Helene-Tiefbau, Witten): scale bar $10 \mathrm{~mm}$. - D - fragment of ultimate pinna attached to penultimate rachis (arrowed): MB.Pb.2003/788 - Gothan 1913, pl. 1, fig. 3 (locality - mine near Orzesche, Upper Silesia, Poland): scale bar $10 \mathrm{~mm}$. E - fragment of penultimate rachis (P) and aphlebia-like organs (arrowed): MB.Pb.2003/212 - Gothan (1929), pl. 6, fig. 4 (locality - Flöz 4, Zeche Baldur, Dorsten): scale bar $10 \mathrm{~mm}$. 


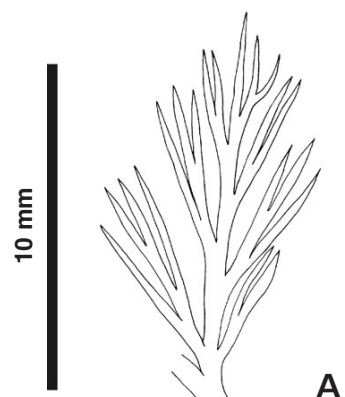

A
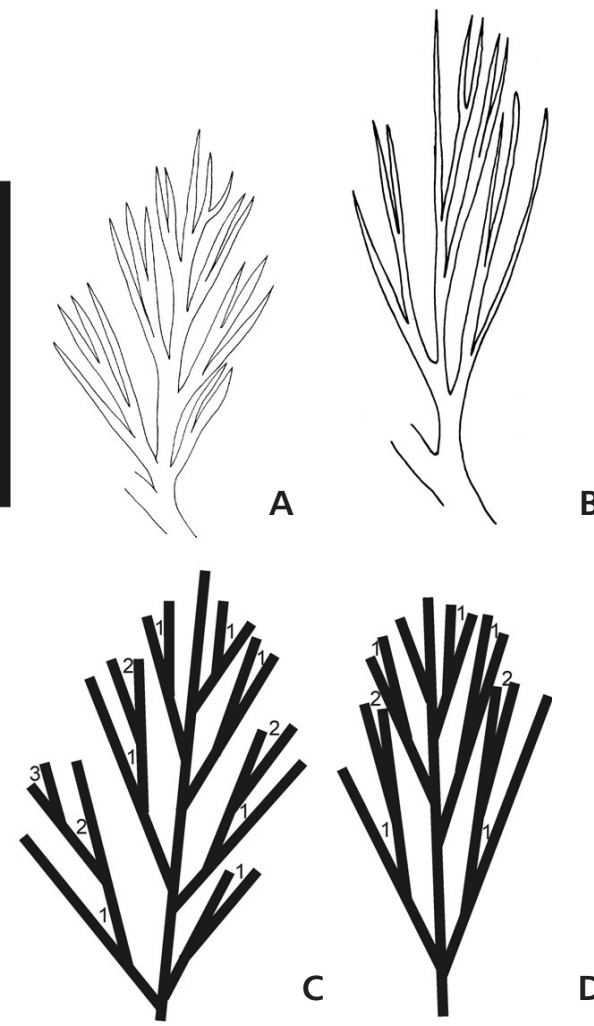

C

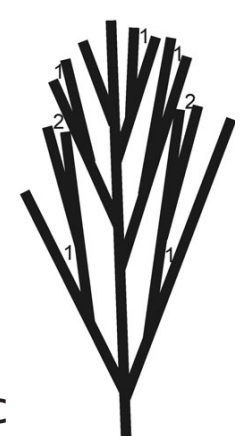

D

Figure 12. A - pinnule of Rhodeites gutbieri (Ettingshausen) Němejc (specimen E 4942). • B - pinnule of Rhodeopteridium subpetiolatum (Potonié) comb. nov. of Gothan's specimen MB.Pb.2003/214. • C - Rhodeites gutbieri - schematic drawing of dividing lateral veins (max. 3 times). $-\mathrm{D}$ - Rhodeopteridium subpetiolatum - schematic drawing of dividing lateral veins (max. 2 times).

Museum in Pilsen) very interesting sporangia were obtained, probably from $R$. gutbieri, which will be published as Echinosporangites libertite Pšenička \& Bek. Ec. libertite has never been observed in organic connection with any of the associated pinnules or rachises. Associated plant remains included Selaginella sp., Corynepteris angustissima (Sternberg) Němejc and R. gutbieri. Although we cannot be sure about the precise affinity of Ec. libertite dispersed sporangia [with spores comparable to Schopfites Kosanke (Pšenička \& Bek 2009)], we have some indirect evidence identifying their parent plants. Sporangia and in situ spores of two of them (Selaginella sp. and C. angustissima) are known and are not comparable with the morphology of $E c$. libertite. Thus the supposition arises that $R$. gutbieri, as the third associated plant, is the hypothetical parent plant of these sporangia. If sporangia Ec. libertite really belongs to $R$. gutbieri, it may belong to the true ferns.

The affinity to ferns is also supported by the fact that ultimate pinnae are organised in pairs, which is known in zygopterid ferns such as C. angustissima (Sternberg) Němejc. C. angustissima as well as $R$. gutbieri have dense haired and sinusoid warped penultimate rachises (or stems). In contrast to $R$. gutbieri, $C$. angustissima produced

aphlebia-like structures on the rachis. Nevertheless, it is not possible to clearly refer $R$. gutbieri to the fern, pteridosperm or progymnosperm plant group.

\section{Comparison of cuticles}

Cuticles from Rhodeites gutbieri are described for the first time during palaeobotanical history. A general database of Carboniferous fern or fern-like cuticles still does not exist. The papers that deal with this topic are more or less isolated (i.e. Barthel 1962, Pšenička 2005). Therefore comparisons of cuticles are more or less limited.

Barthel (1962) described similar cuticles from Sphenopteris adiantoides (Schlotheim) H. Potonié: cuticles that are not differentiated into costal and intercostal fields; ordinary cells are elongated, 15-25 $\mu \mathrm{m}$ wide and 100-250 $\mu \mathrm{m}$ long; adaxial and abaxial cuticles contain trichome bases; stomata occur on the abaxial cuticle only; stomata are 35-45 $\mu \mathrm{m}$ long and $25 \mu \mathrm{m}$ wide. The common characteristic of $S$. adiantoides and $R$. gutbieri cuticles is the lack of differentiation in costal and intercostal fields. But Barthel (1962) pointed out that this feature depends on preservation and size of cuticles. Other characteristics are the elongation of cells and that adaxial/abaxial cuticles exhibit trichome bases $15 \mu \mathrm{m}$ in cross-section. S. adiantoides also has palmatopterid type pinnules, characterised by deeply lobed pinnule to laminar segments, corresponding with veins (Barthel 1962, pl. 6, fig. 88) which resemble the palmatopterid pinnules of the studied species. Nevertheless, Barthel (1962) described pinnules of S. adiantoides as hypostomatic (stomata on lower surface only) while pinnules of $R$. gutbieri appear rather aphistomatic (stomata on both surfaces). Barthel (1962) also mentioned the 35-45 $\mu \mathrm{m}$ size of $S$. adiantoides stomata while $R$. gutbieri has sunken stomata 20-27 $\mu \mathrm{m}$ long.

The $R$. gutbieri stomata are not only aphistomatic but also anomocytic (subsidiary cells are indistinguishable from other cells in size and aspect). This type of stomata appears in most true fern families (Van Cotthem 1970). Even if this type of stoma points to a relationship with some fern species, pinnules of $R$. gutbieri bear glandular trichomes, which have not been described in any living ferns.

\section{Ecological comment}

All known specimens of Rhodeites gutbieri occur in an about $0.5 \mathrm{~m}$ thick in situ volcanic ash bed at the base of the Whetstone Horizon (Radnice Member, Kladno Formation). Mašek (1963) interpreted the basal bed of the Whetstone Horizon as a rhyolitic sand-grained tuff, and the laminated "whetstone" above it as a graded ash tuff bed. The 


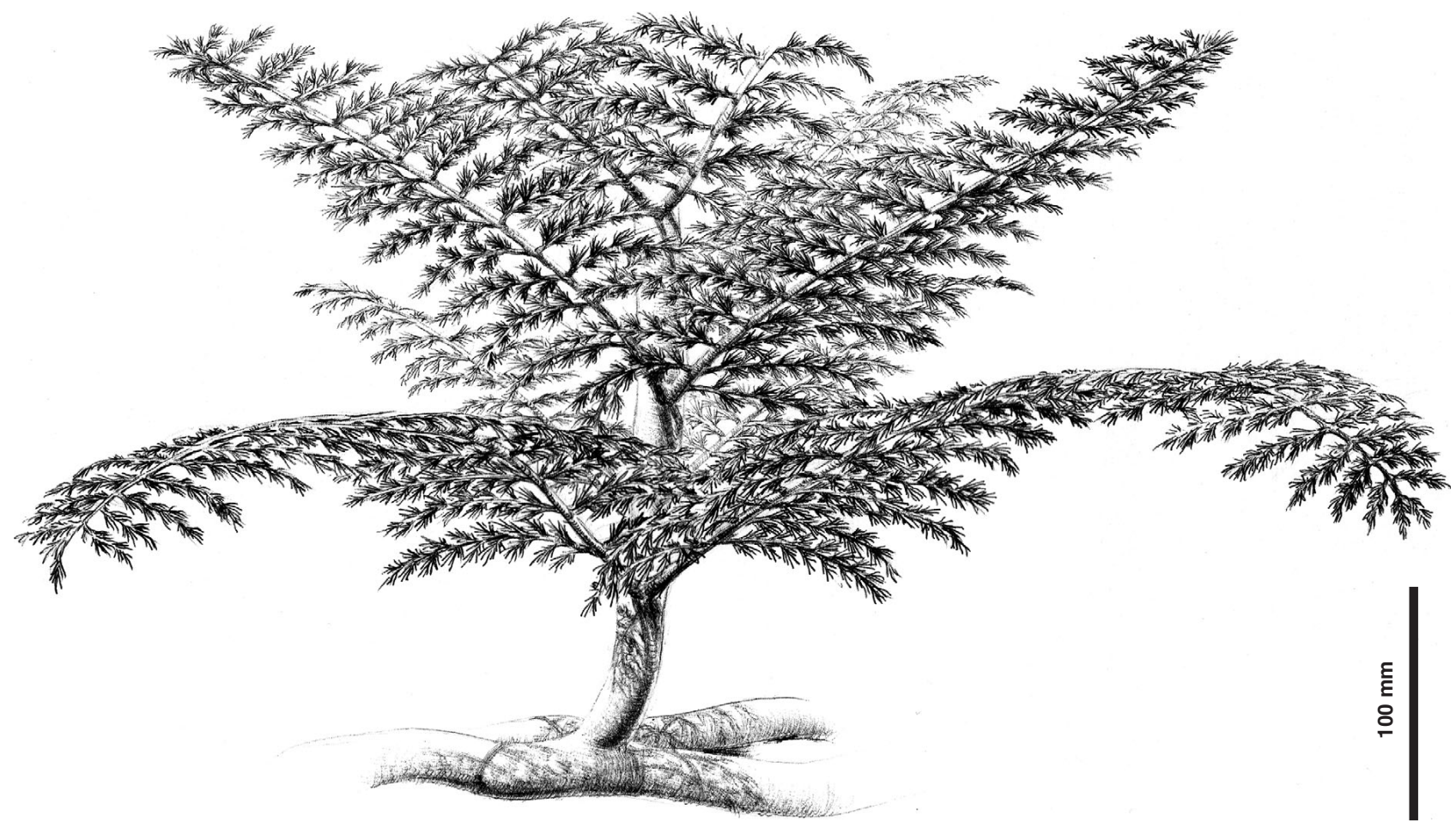

Figure 13. Idealised reconstruction of Rhodeites gutbieri (Ettingshausen) Němejc.

in situ volcanic ash buried plants at the place of their original growth (Opluštil et al. 2007). Taphocoenosis preserved in the tuff bed more or less corresponds with original phytocoenosis. It is also possible to recognise individual plant storeys (Opluštil et al. in press). R. gutbieri is associated with Selaginella sp., $C$. angustissima (on the specimen from the Doubrava locality), C. angustissima and Sphenophyllum majus (Bronn) Kidston (on the specimen from the Svinná locality). All specimens of these plants occur near the base of the in situ volcanic ash bed about 0-30 mm above roof of the Lower Radnice Seam. This part of the bed mostly contains remains of plants that belonged to the herbaceous storey. Due to this fact, $R$. gutbieri was also part of this storey. The ultimate rachis (or stem) is notably long (more than $160 \mathrm{~mm}$ ) and s-warped, and resembles a stem of zygopterid ferns as for example $C$. angustissima. We assume that $R$. gutbieri had a similar habit (Fig. 13) and life strategy, as creeping and climbing plants occupying the herbaceous storey. The flora preserved in the tuff bed colonized the planar (rheotrophic) mire occasionally supplied by clastics during flooding events (Opluštil et al. in press). R. gutbieri is therefore an element of disturbed peat to mixed peat-clastic mires.

The specimen of Rh. subpetiolatum from Orzesche in Upper Silesia, Poland (MB.Pb.2003/0788) is associated with Sphenophyllum cuneifolium a widespread scrambling plant and the specimen MBPb.2003/0212 with Calamites sp., Mariopteris muricata and even with Sph. cuneifolium.

\section{Stratigraphical distribution of both studied species}

The stratigraphical distribution of both studied species is clearly differentiated into two main stratigraphical horizons as Fig. 14 shows. Rhodeites gutbieri is limited to deposits of the Lower Moscovian (Bolsovian age). The regional distribution of Rhodeites gutbieri is the Pilsen Basin (Czech Republic) and the Sarro-Lorrain Basin (France) ("Sphenopteris coemansii" sensu Brousmiche 1983). Rhodeopteridium subpetiolatum in contrast is characteristic for the Bashkirian Stage (from Yeadonian to Duckmantian age) (Fig. 14) and occurred in the Intra-Sudetic Basin area (Poland). This species also occurred in the upper Bashkirian Stage (Duckmantian) in the Upper Silesian Basin (Poland), East Pennine and Burnley basins (UK) (Fig. 14). In Germany Rhodeopteridium subpetiolatum is known from the Ruhr Basin and belongs to the middle Bashkirian Stage (Yeadonian and Lengsettian).

The specimens from Héraclée Basin (Turkey) were reported from Duckmantian/Bolsovian age deposits (Fig. 14) and are thus outside the stratigraphical distribution of other known specimens of Rhodeopteridium subpetiolatum as well as Rhodeites gutbieri. Based on the fact that Zeiller's specimens look poorly preserved and fragmentary, and are only mentioned in the text by Ralli (1933), the occurrence of Rhodeopteridium in this Turkish coal basin is not sufficiently secured. 


\section{Systematic palaeobotany}

Class Incertae sedis

Order Incertae sedis

Family Incertae sedis

\section{Rhodeites Němejc (1937) emend.}

Type species. - Rhodeites gutbieri (Ettingshausen, 1854) Němejc, 1928. Czech Republic. Pennsylvanian, lower Moscovian (Bolsovian).

Emended diagnosis. - Pinnatifid fronds; ultimate pinnae gradually tapering; tip of ultimate rachis with poorly differentiated lobes and very narrow lamina; ultimate rachises straight or slightly sinusoidal at the distal end of the ultimate pinna, attached to penultimate rachis in pairs; pinnules palmatopterid-type, alternating on ultimate rachis, segmented, each segment differentiated into laminar lobes with sharp tips; aphlebia-like organs present.

\section{Rhodeites gutbieri (Ettingshausen, 1854) Němejc, 1936 emend.}

1854 Sphenopteris gutbieri n.; Ettingshausen; pl. 19, figs 1, 2. 1928 Rhodea subpetiolata Potonié. - Němejc; p. 6, figs 1, 2. 1937 Rhodeites gutbieri (Ettingshausen) n. - Němejc; p. 6. 1963 Rhodeites subpetiolata (Potonié) Němejc. - Němejc; p. 381 , pl. 42 , fig. 4.

1983 Sphenopteris coemansii Andrae. - Brousmiche; pl. 84, figs 2-4.

Lectotype. - Fig. 2C, D; specimen GBA 1854/009/0021; housed in Geologische Bundesanstalt in Vienna (Austria).

Type locality. - Svinná locality; Radnice Basin (Czech Republic).

Type horizon. - Whetstone Horizon, Radnice Member, Kladno Formation; Pennsylvanian, lower Moscovian (Bolsovian).

Diagnosis. - Pinnatifid fronds; penultimate rachis sinusoid warped, densely covered by uniseriate, multicellular trichomes $0.2-0.4 \mathrm{~mm}$ long. Ultimate pinnae gradually tapering from $\mathrm{ca}$ middle part to the tip; tip of ultimate rachis with poorly differentiated lobes with very narrow lamina. Ultimate rachises straight or very slightly sinusoidal at the distal end of the ultimate pinna, attached to penultimate rachis in pairs.

Pinnules palmatopterid-type, alternating on ultimate rachis at $30^{\circ}-40^{\circ}, 10-13 \mathrm{~mm}$ long and $6-8 \mathrm{~mm}$ wide.
Pinnules up to 7 times segmented. Each segment differentiated in up to 4 laminar lobes with sharp tips. The midvein preserved as marked central; lateral veins branching off at angles around $40^{\circ}$ to $70{ }^{\circ}$ running in every laminar segment of the pinnules, divided up to 3 times. Aphlebia-like organs present near base of ultimate pinna (on lower side).

Cuticles: Cuticle of abaxial as well as adaxial side thick and more or less identical. Sunken, anomocytic stomata rare on abaxial as well as on adaxial sides. Cells of adaxial and abaxial cuticles differentiated in costal and intercostal fields but the margin of both fields obscure. Costal cells elongateand tetragonal (polygonal). Anticlinal walls straight. Adaxial and abaxial cuticles covered by glandular trichomes located in costal fields, consisting of a basal cell and globose bodies.

Class Pteridospermopsida?

Order Incertae sedis

Family Incertae sedis

\section{Rhodeopteridium Zimmermann, 1959}

Rhodeopteridium subpetiolatum (Potonié, 1889) comb. nov.

1892 Rhacopteris subpetiolata n.; Potonié; p. 26, text-fig. p. 27.

1896 Rhacopters subpetiolata n. - Potonié; p. 21, text-fig. 6.

1899 Rhacopteris subpetiolata n. - Potonié; p. 132, text-fig. 121.

1899 Rhodea subpetiolata (Potonié) Zeiller; Zeiller; p. 27.

1912 Rhodea subpetiolata (Potonié) Zeiller. - Gothan; pl. 3, figs 6,7 .

1913 Rhodea subpetiolata (Potonié) Zeiller. - Gothan; pl. 1 , fig. 3 .

1921 Rhodea subpetiolata (Potonié) Zeiller. - Gothan \& Potonié; p. 82, fig. 75.

1923 Rhodea subpetiolata (Potonié) Zeiller. - Gothan; p. 43 , fig. 41 .

1923 Rhodea subpetiolata (Potonié) Zeiller. - Kidston; pl. 59 , fig. 1.

1923 Rhodea gutbieri (Ettingshausen) n. - Kidston; pl. 59, figs 2,3 .

1929 Rhodea subpetiolata (Potonié) Zeiller. - Gothan; p. 20, pl. 1, figs 2, 3; pl. 6, fig. 4 .

1954 Rhodea subpetiolata (Potonié) Zeiller. - Gothan \& Weyland; p. 133, fig. 111.

1957 Rhodea subpetiolata (Potonié) Zeiller. - Gothan \& Remy; p. 99, figs 89, 90.

1957 Rhodea (Zeilleria) subpetiolata (Potonié) Zeiller. Stopa; p. 186, pl. 25, figs 1-3. 


\begin{tabular}{|c|c|c|c|c|c|c|}
\hline \multirow{3}{*}{ localities chronostratigraphy } & \multicolumn{6}{|c|}{ Pennsylvanian } \\
\hline & \multicolumn{4}{|c|}{ Bashkirian } & \multicolumn{2}{|c|}{ Moscovian } \\
\hline & \begin{tabular}{|l|l|l|l|}
$\mathrm{Ch}$ & $\mathrm{A}$ & $\mathrm{K}$ & $\mathrm{M}$ \\
\end{tabular} & $\mathrm{Y}$ & $\mathrm{L}$ & $\mathrm{D}$ & $\mathrm{B}$ & $\mathrm{A}$ \\
\hline CZ Radnice Basin & & & & & & \\
\hline CZ Pilsen Basin & & & & & & \\
\hline TR Héraclée Basin & & & & & & \\
\hline Intra-Sudetic Basin Waldenburg & & & & & & \\
\hline $\begin{array}{ll}\text { CZ Upper Silesian Basin } & \text { Czerwionka } \\
& \text { Parušovice }\end{array}$ & & & & & & \\
\hline $\begin{array}{lr}\text { GR Ruhr Basin } & \text { Dortmund } \\
& \text { Dorsten } \\
\text { Witten }\end{array}$ & & & & & & \\
\hline FR Saar-Lorraine Basin & & & & & & \\
\hline East Pennine Basin & & & & & & \\
\hline UK Burnley Basin & & & & & & \\
\hline
\end{tabular}

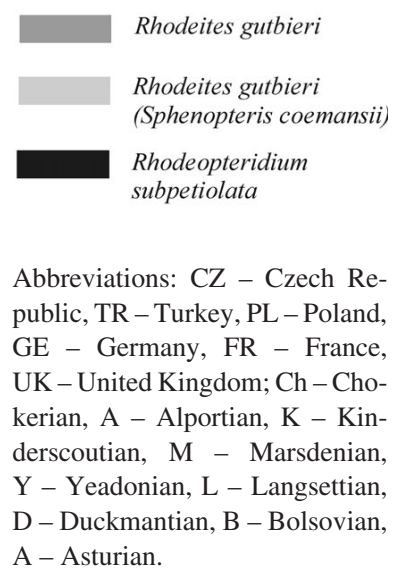

Figure 14. Stratigraphical distribution of Rhodeites gutbieri (Ettingshausen) Němejc and Rhodeopteridium subpetiolatum (Potonié) comb. nov. from basins where both species are know.

1977 Rhodeites gutbieri (Ettingshausen) Němejc. - Remy \& Remy; p. 206, fig. 91.

1991 Rhodeites gutbieri (von Ettingshausen) Němejc. Josten; p. 230, pl. 101, fig. 5; pl. 103, fig. 3.

Holotype. - See Fig. 10A, B; Specimen MB.Pb.2003/0960; Museum für Naturkunde zu Berlin, Germany.

Type locality. - Fürstlicher Tiefbau, near Waldenburg, Intra Sudetic Basin, Poland.

Type horizon. - Pennsylvanian, Westphalian A/B (Langsettian/Duckmantian).

Diagnosis. - Ultimate rachises nearly straight with somewhat rigid appearance; three dimensional, pseudohelical arrangement of ultimate rachises; Pinnules palmatopterid-type, alternate on ultimate rachis at acute angles of around $30^{\circ}$ to $50^{\circ}, 10-15 \mathrm{~mm}$ long and 6-9 mm wide, with a length/width ratio of $\sim 1.8$, differentiated in up to four segments, build up by one to (seldom) four lobes; lobes straight and showing very narrow laminae, their tips are tapering off; Aphlebia-like organs present. Fructification of Zeilleria-type.

Cuticles: Cells of cuticles slightly differentiated in costal and intercostal fields, both areas merging without any clear border, cells elongate (length/width ratio 4:1) and tetragonal (polygonal). Anticlinal walls straight.

\section{Acknowledgements}

This work was supported by the Grant Agency of the Czech Republic (205/07/1059), Grant Agency of Academy of Science (IAA 301110701) and IGCP 469 projects. We would like to thank Anna Langrová, and Zuzana Korbelová from the Institute of Geology, Academy of Science of the Czech Republic, Prague for examination under CAMECA SX100 scanning electronic microscope (SEM). We also thank Barbara Meller for taking photographs of Ettingshausen's type housed in the Geologische Bundesanstalt, Wien. Milan Libertín (National Museum in Prague) is cordially acknowledged for help with the study of Němejc's specimens. We acknowledge J. Svoboda for the hand drawing of the Rhodeites plant. We would like to thank to C. Radke for taking photographs of Gothan's specimens and J. Dunlop for revision of English.

\section{References}

BARTHEL, M. 1962. Epidermisuntersuchungen an einigen inkohlten Pteridospermenblättern des Oberkarbons und Perms. Geologie 11(33), 1-140.

Brousmiche, C. 1983. Les Fougéres sphénoptéridiennes du Bassin Houiller Sarro-Lorrain. Société Géologique du Nord $10,1-480$.

Broussier, F. \& BerTRAND, P. 1911. Description d'un Rhodea trouvé dans le terrain houiller d'Aniche. Annales de la Société Géologique du Nord 40, 314.

DABER, R. 2003. Sphenopteris coemansi Andrae - neue, aussagefähige Funde. Feddes Repertorium 114, 429-436. DOI 10.1002/fedr.200311008

ETTINGSHAUSEN, C. 1854. Die Steinkohlenflora von Radnitz in Böhmen. Abhandlungen der Kaiserlich-königlischen geologischen Reichsanstalt, Abteilung 3(2), 1-74.

Gillespie, W.H., Clendening, J.A. \& PFefFerkorn, H.W. 1978. Plant fossils of West Virginia. $172 \mathrm{pp}$. Geological and Economic Survey, Morgantown, West Virginia, Education Series ED-3A, West Virginia, USA.

GothAN, W. 1912. Einige bemerkenswerte neuere Funde von Steinkohlenpflanzen in der Dortmunder Gegend. Verhandlungen des Naturhistorischen Vereins der preussischen Rheinlande und Westfalens 69, 239-253.

Gothan, W. 1913. Die oberschlesische Steinkohlenflora I. 
Theil: Farne u. Farnähnliche Gewächse (Cycadofilices bezw. Pteridospermen). Abhandlungen der Königlich Preussischen geologischen Landesanstalt, N.F. 75, 1- 278.

GOTHAN, W. 1923. Karbon und Perm-Pflanzen. In GÜRICH, G. Leitfossilien. Ein Hilfsbüch zum Bestimmen von Versteinerungen bei geologischen Arbeiten und der Sammlung und im Felde III. 187 pp. Borntraeger, Berlin.

Gothan, W. 1929. Die Steinkohlenflora der westlichen paralischen Carbonreviere Deutschlands. Arbeiten aus dem Institut für Paläobotanik und Petrographie der Brennsteine 1(1), 1-48.

Gothan, W. \& POTONIÉ, H. 1921. Lehrbuch der Palaeobotanik. 538 pp. Borntraeger, Berlin.

Gothan, W. \& REMY, W. 1957. Steinkohlenpflanzen. 248 pp. Glückauf, Essen.

Gothan, W. \& WeYland, H. 1954. Lehrbuch der Paläobotanik. 535 pp. Akademie-Verlag, Berlin.

JENNINGS, J.R. 1976. The morphology and relationships of Rhodea, Telanmgium, Telangiopsis, and Heterangium. American Journal of Botany 65, 1119-1133. DOI $10.2307 / 2441657$

Josten, K.-H. 1991. Die Steinkohlen-Floren Nordwestdeutschlands, Text- und Tafelband. Fortschritte in der Geologie von Rheinland und Westfalen 36, 1-434.

KIDSTON, R. 1923. Fossil plants of the Carboniferous rocks of Great Britain. Memoirs of the Geological Survey of Great Britain, Palaeontology 2(3), 199-274.

MAŠEK, J. 1963. Složení a vznik brouskového horizontu ve středočeské kamenouhelné pánvi. Časopis pro mineralogii a geologii 8, 175-177.

NĚMEJC, F. 1928. Rhodea subpetiolata Pot. sp. nový typ listový pro středočeské kamenouhlené pánve. Rozpravy České akademie věd a umění, Tř́da II 36(40), 1-6.

NĚMEJC, F. 1937. The sphenopterides stated in the Permocarboniferous of Central Bohemia (a preliminary report. I part). Věstník Královské České společnosti nauk, Třída II, 1-24.

NĚMEJC, F. 1963. Paleobotanika II. 523 pp. Československá akademie věd, Prague.

OPLUŠTIL, S., PŠENIČKA, J., LIBERTÍN, M. \& ŠIMŮNEK, Z. 2007. Vegetation patterns of Westphalian and Lower Stephanian mire assemblages preserved in tuff beds of the continental basins of Czech Republic. Review of Palaeobotany and Palynology 143, 107-154. DOI 10.1016/j.revpalbo.2006.06.004

OpluŠTIL, S., PŠENIČKA, J., LIBERTÍN, M., BASHFORTH, A.R., ŠIMŮNEK, Z., DRÁBKOVÁ, J. \& DAŠKOVÁ, J. In press. A Middle Pennsylvanian (Bolsovian) peat-forming forest preserved in situ in volcanic ash of the Whetstone Horizon in the Radnice
Basin, Czech Republic. Review of Palaeobotany and Palynology.

POTONIÉ, H. 1892. Über einige Carbonfarne. Jahrbuch der Koeniglich Preussischen geologischen Landesanstalt und Bergakademie zu Berlin für das Jahr 1889 10, 26-27.

Potonié, H. 1896. Die floristische Gliederung des deutschen Carbon und Perm. Abhandlungen der Königlich Preussischen geologischen Landesanstalt, N.F. 21, 1-58.

POTONIÉ, H. 1899. Lehrbuch der Pflanzenpalaeontologie. 402 pp. Duemmler, Berlin.

PŠENIČKA, J. 2005. Taxonomy of Pennsylvanian-Permian ferns from coal Basins in the Czech Republic and Canada. 185 pp. Ph.D. thesis, Faculty of Science, Charles University, Prague, Czech Republic.

PŠENIČKA, J. \& BEK, J. 2009. A new reproductive organ Echinosporangites libertite gen. and sp. nov. and its spores from the Pennsylvanian (Bolsovian) of the Pilsen Basin, Bohemian Massif, Czech Republic. Review of Palaeobotany and Palynology 155, 145-158. DOI 10.1016/j.revpalbo.2007.12.004

RALLI, G. 1933. Le bassin houiller d'Héraclée et la flore du Culm et du Houiller Moyen. 100 pp. Zellitch, Instanbul.

REMY, W. \& REMY, R. 1977. Die Floren des Erdaltertums. 468 pp. Glückauf, Essen.

SCHIMPER, W.P. 1869. Traité de paléontologie végétale ou la flore du monde primitif dans ses rapports avec les formations géologique et la flore du monde actuel. Vol. I. 740 pp. J.B. Baillière et fils, Paris.

STERNBERG, K.M. 1838. Versuch einer geognostischen botanischen Darstellung der Flora der Vorwelt. Vol. II, 7/8, 81-220 pp. Gotlieb Hässe Söhne, Prague.

STOPA, S.Z. 1957. Les feuilles de fougères (Pterodophylla) du Namurien Supérieur et du Westphalien le plus bas dans le Bassin houiller de la Haute Silésie. Instytut Geologiczny, Prace 13, 1-208.

STUR, D. 1877. Beiträge zur Kenntnis der Flora der Vorwelt. I. Heft 2, Die Culm-Flora der Ostrauer und Waldenburger Schichten. Abhandlungen der Kaiserlisch-königlichen geologischen Reichsanstalt 8, 1-366.

VAN COTTHEM, W. 1970. Comparative morphological study of the stomata in the Filicopsida. Bulletin du Jardin Botanique National de Belgique 40(2), 81-239. DOI 10.2307/3667713

ZEILLER, R. 1899. Étude sur la flore fossile du bassin houiller d'Héraclée. Mémoires de la Société Géologique de France, Paléontologie 21, 1-91.

Zimmermann, W. 1959. Die Phylogenie der Pflanzen. 777 pp. Gustav Fischer, Stuttgart. 